\title{
The rhetoric of redistribution ${ }^{1}$
}

\author{
Ben Jackson
}

Hobson, lecturing on economics last night on the BBC, referred to the revolution which had occurred in our society by the imposition of taxes upon wealth, \& the heavy death duties which prevented it from being passed on. And D. [Lloyd George], looking at me significantly, pointed his finger to his own breast, meaning: I did it.

(Lloyd George: a Diary by Frances Stevenson, entry for 29.10.1934, quoted in Clarke 1974: xxxiv)

\section{Introduction}

The historic distributive achievements of social democracy - the welfare state, the progressive taxation of income and wealth, the regulation of the labour market - were not simply the fruit of social pressures and the expertise of sympathetic intellectuals. The implementation of these reforms also required the creative exercise of power by adept political leaders. These leaders persuaded voters of the value of the welfare state or progressive taxation in accessible, even demotic, language and constructed electoral coalitions that would support parties committed to these measures. But this great progressive tradition of public oratory on behalf of the poor and underprivileged has been absent from politics in Britain and the United States in recent years. Both the Labour and Democratic parties conspicuously struggled to articulate a compelling public case for reducing poverty or narrowing economic inequality when they returned to office in the 1990s. In Britain, Labour's adoption of centrist rhetoric after 1994 famously proved compatible with so-called 'redistribution by stealth': a concerted attempt to engineer non-negligible but unpublicised improvements in the incomes of the working poor. However, these welcome measures have not reversed the large economic inequalities created during the 1980s (see Brewer et al. 2008), and Labour's underlying commitment to a fairer Britain 
proved to be less than robust when confronted in 2007 with a concerted Conservative counter-attack over inheritance tax. Arguments in favour of inheritance tax apparently eluded leading Labour politicians at this crucial conjuncture. Similarly, in the United States, the Democrats were unable to find a convincing answer to the Republican repeal of the estates tax in 2001. As a result, the Democrats comprehensively lost the argument over whether or not it is fair to tax inherited wealth (for the gory details, see the indispensable Graetz and Shapiro 2005). Hovering in the background of these and similar debates in other nations lurks the widely discussed proposal to abolish progressive taxation of income and wealth altogether and replace it with a flat tax (see e.g. The Economist 2005). Although at present this seems to be a distant prospect, if recent political history teaches us anything it is that the extreme libertarian think-tank pamphlet of today can very quickly become the government policy of tomorrow.

The formulation of an attractive public discourse about economic redistribution is therefore a matter of some urgency for parties of the left. On it rests the defence of the hard-won achievements of the past and the mobilisation of popular support for fresh initiatives aimed at reducing poverty and economic inequality. But how are such political arguments to be constructed? What sort of language can legitimise the transfer of resources from one group of citizens to another? In answering these questions, one instructive source of information is likely to be historical. After all, at certain points in the past, radical politicians did manage to articulate and win arguments about economic redistribution. In this chapter I will provide some evidence about how this was done. I will also argue that contemporary perceptions of this genre of political rhetoric are often inaccurate: modernisers who have laboured to renew the popular appeal of leftwing parties see 'old' social democratic language as unnecessarily alarmist to middle-income voters and premised on an anachronistic appeal to an ever-diminishing working class. The evidence assembled in this chapter suggests that the historical premises of this argument are in fact mistaken. The actual rhetoric of redistribution deviated in important respects from the interpretation of it deployed in present-day political polemics, and this in turn raises the possibility that earlier styles of progressive rhetoric might yet be renovated for use in contemporary political arguments.

To substantiate these points, I will identify certain important features of the rhetoric used in the past to argue for progressive taxation, welfare programmes, the regulation of the labour market, and other policy measures intended to lighten the burdens of the poor by increasing burdens on the better off. For the sake of brevity, I will refer to these measures collectively as 'redistribution'. I will draw on evidence from three important episodes of progressive policy-making and electioneering: first, the rhetoric used to 
justify 'new liberal' welfare reforms and fiscal policy in Edwardian Britain, in particular the speeches of Lloyd George; second, the political discourse of the New Deal in the United States in the 1930s, especially speeches and broadcasts by Franklin Roosevelt; and, finally, proposals in Britain during and after the Second World War about the character of post-war reconstruction, as advocated by prominent politicians in the Labour Party, and also by other influential figures such as William Beveridge. In spite of the differences between these episodes of social reform (and in particular between the British and American cases), I will nonetheless maintain that their rhetorical justification exhibited certain illuminating similarities. ${ }^{2}$

I must stress at the outset that this chapter is expressly interpretive rather than quantitative in its approach. It identifies the ideological structure and animating political strategy of redistributive political discourse through the methods of textual analysis familiar to scholars of political thought. ${ }^{3}$ Implicit in this approach is the assumption that, while the scrutiny of principles of social justice under ideal conditions is an indispensable aspect of political theory, it is equally important to investigate how political language is used strategically, as a weapon in partisan political warfare and the struggle for power. Such strategic considerations are vital because they identify important constraints that will ultimately govern the character of the arguments for social justice suitable for our non-ideal world (here I draw my inspiration from work such as Freeden 1996; Skinner 2002; Stears 2005). One consequence of this focus on political thought is that the causal claims made in this chapter are very limited: at no point do I want to suggest, for example, that suitably persuasive rhetoric is, or was, in itself sufficient to engineer public support for economic redistribution regardless of prevailing social and economic circumstances. Instead, my working assumption is simply that the public arguments of politicians have at least some influence over the outcome of policy debates and the mood of public opinion. I leave this relatively uncontroversial assumption undefended in order to focus on my specific aim in this chapter, which is simply to clarify the character of political rhetoric in the past rather than to assign it any precise causal role in bringing about political change. What is presented here is therefore a necessary preliminary exercise to a more fine-tuned discussion of the part played by rhetoric in either past or present distributive controversies.

In this spirit, I will identify three important aspects of redistributive rhetoric: first, its critique of prevailing distributive patterns via an appropriation of a populist understanding of the 'public interest'; second, the specific political ideals that redistribution was said to advance; and third, the assumptions about political agency that underpinned this rhetoric and that it helped to disseminate to a wider public. 


\section{Economic royalists versus Oliver Twist: redistribution and the public interest}

Rhetoric is the art of persuading a particular audience. In Aristotle's words, it is 'the faculty of observing in any given case the available means of persuasion'. On Aristotle's account, the available means will not always be logical, but will rather be a combination of the credibility of the speaker's character, the emotions the speaker arouses in the audience, and the reasoned arguments that the speaker can marshal. Through this combination of ethos, pathos and logos, argued Aristotle, political arguments are fought and won (Aristotle 1984, Bk 1, Ch. 2: 2155). Political rhetoric therefore does not succeed by the strength of its logic alone: it prospers by packaging, compressing and sometimes even bypassing logical reasoning so that arguments are rendered accessible and plausible to a target audience. The first characteristic of the rhetoric of redistribution I want to examine offers an apt illustration of the role played in political persuasion by both emotional appeals and the personal credibility of a speaker: the critique mounted by progressive politicians of the prevailing distribution of wealth and opportunity. In essence, this critique drew a sharp dividing line between the interests of the rich and the interests of the community as a whole.

The initial step along this road was simply to use emotive terms to juxtapose the parlous state of the poor with the privilege enjoyed by the wealthy. For example, Lloyd George contrasted 'the profligate extravagance with which land by the square mile is thrown away upon stags and pheasants and partridges' with 'the miserly greed with which it is doled out for the habitations of men, women and children' (17.10.1910, London, BT: 337). Crucial to the liveliness and power of this language was the sparing use of statistical information. Certain striking facts were undoubtedly highlighted, but not at the expense of memorable narratives about the fate of particular individuals or social groups. Popular support for redistribution was initially elicited by inviting the voters to empathise with the deprivations suffered by the poor and the needy, sometimes by drawing on a common stock of cultural memories and references. Herbert Morrison defended the record of the 1945 Labour Government by contrasting Labour's reforms with the 'sad picture of the bad old days' disclosed in the recently released film of Oliver Twist and with his own memories of his childhood:

We have only to recall the drab misery of the back streets of our cities in the last century - the lack of pure water, the sewerage conditions, the employment of young children, the disgrace and crime of poverty, the dark squalor of birth with the ignorant tolerance of death of children and mothers, the slums with their lurid 'pubs', the poverty, destitution and heaped-up misery of it all - to wonder at the change which has taken place and, I think, to be 
thankful that the heart of our people went through it unbroken. (12.7.1948, London, PR: 128-9)

At the Democratic Party National Convention in Philadelphia in 1936, at the height of partisan controversy over the New Deal, speech after speech addressed not only facts but 'the human values far beyond these figures', forcefully contrasting the conditions before Roosevelt's Presidency - when 'destitution walked every street' - with the success of government intervention in ensuring 'that the cheeks of little children shall not grow gaunt' and ending 'starvation, bread lines and soup kitchens'. The authority of these points was often bolstered by biblical references - the New Deal was said to embody the Sermon on the Mount, for instance, or to answer the question 'Am I my brother's keeper?' (PDNC: 50, 281, 229, 214, 225, 51; see also $187,230,244,255-6,276,281-4)$. The public discussion of poverty and its associated hardships in this direct, home-spun fashion carried as much and perhaps even more weight in public debate than the use of statistical evidence, since it was often more effective at attracting the emotional loyalties of the public and drew on the authority of certain widely known cultural references. ${ }^{4}$

However, this was only the first step in arousing popular outrage at social injustice - much stronger contrasts between rich and poor were also made. Progressive politicians usually deployed two important but cutting redescriptions of the behaviour of certain wealthy citizens and their allies: as 'parasitic' and as 'selfish'. ${ }^{5}$ First, they characterised some of the rich as 'parasitic' since existing property entitlements did not always reward effort. Crudely speaking, some people were said to be rich either because of large capital incomes that expanded without regard to the amount of work performed by the beneficiary or they accrued resources because of various kinds of market-based luck unrelated to productive contribution. As Lloyd George put it, too little attention was given to the problem of 'unemployment amongst the upper classes'. The 'idle rich', he continued, enjoyed 'lives of luxurious indulgence, and a great multitude of others live lives of arduous toil without earning sufficient food and raiment and repose' (17.10.1910, London, BT: 339-40). Inherited wealth was indeed simply 'a fatty degeneration of property', observed the Labour Chancellor of the Exchequer Hugh Dalton as he raised death duties in 1946: such wealth tempted those in receipt of it to 'become lazy and thriftless, unambitious and unenterprising'. ${ }^{6}$ By contrast, it was argued, those on low incomes worked hardest of all and received miserly compensation for their efforts. As Henry Ellenbogen, a Democratic congressman, put it in 1935, the low paid were 'the builders of America', who 'dug its ditches, paved its roads, operated its machines, constructed its buildings' (19.8.1935, Congress, 
in Zinn 1966: 283). ${ }^{7}$ Herbert Morrison even proclaimed that the Labour Party 'stands up for all the useful people' (13.12.1947, radio broadcast, PR: 142). A reciprocal relationship between productive contribution and social rights was therefore central to the justification of economic redistribution: redistributive measures were presented as a just return for the valuable social service rendered by the industrious poor (Freeden 2003: 12-13; White 2003: 214-16, 218).

Second, in addition to suggesting that the behaviour of certain wealthy citizens and their allies was 'parasitic', progressive politicians also argued that the economic and political behaviour of the rich could be 'selfish', since many of them were either directly responsible for the exploitative pay and conditions suffered by the poor or indirectly responsible by opposing remedial political action. The pursuit of self-interest, far from being the praiseworthy quality depicted by the right, was redescribed as sectional behaviour that detracted from the common good. From 1940 onwards, for example, radical populist sentiments coursed through British public debate, with journalists and broadcasters such as J. B. Priestley, George Orwell and Tom Wintringham of the Mirror fiercely criticising the failures of the traditional elites initially in charge of the War effort and shaping the terms of wartime political discussion into one that placed the people's desire for reform at odds with the self-serving agenda of the 'old gang' (Addison 1975: 127-63; Cronin 1984: 122-3). In due course, politicians picked up on these themes. During the 1945 general election campaign, Clement Attlee brusquely rejected the 'pathetic faith' of the Conservatives that 'if every individual seeks his own interest somehow or other the interests of all will be served' and objected to the use of libertarian rhetoric to justify Conservative policy. 'There was a time', Attlee noted, 'when employers were free to work little children for sixteen hours a day', in effect there was 'freedom for the rich and slavery for the poor', and it was only through the action of the state 'that the general public has been protected against the greed of ruthless profit-makers and property-owners' (5.6.1945, radio broadcast, PP: 7, 9; see also Cripps 1946: 20-1, 33, 34).

To ruthlessness and greed was added subversion of the democratic process. In his scintillating acceptance of the Democratic presidential nomination in 1936, Roosevelt drew on the struggle for American independence to establish a parallel between the British royalists who had tried to deny American democracy and the 'economic royalists' who now threatened economic and political life. The wealthy, 'the privileged princes', were 'thirsting for power' and trying 'for control over government itself'. This 'small group' had 'an almost complete control over other people's property, other people's money, other people's labour - other people's lives'. In short, the United States faced 'economic tyranny' from 'the forces of selfishness 
and of lust for power' (27.6.1936, Philadelphia; 31.10.1936, New York; both in FDR vol. 5: 232-3, 568-9). ${ }^{8}$

While the juxtaposition of the very different lives of the rich and poor therefore aimed at winning public support by arousing popular emotions - sympathy for the poor and indignation at the indifference of the rich the personal authority of the speaker also played a significant role in the persuasive appeal of this rhetoric. The very fact that senior political leaders were criticising the rich and powerful, and speaking sympathetically about the hardships faced by the poor, made these sentiments credible in a way that could not be matched by radical activists or political outsiders who might make similar points. The full authority of the offices of the president of the United States or the British Prime Minister and Chancellor of the Exchequer were placed behind this critique of economic inequality, granting importance to political ideas that might otherwise have seemed dangerously radical or impracticable. ${ }^{9}$ 'The President wants you to join a union', ran the famous slogan of the American union leader John L. Lewis, after Roosevelt's National Industrial Recovery Act had been passed into law in 1933, complete with its pro-union clause 7a (Gerstle 1989: 127-8; Anderson 1990: 283-8).

As we have seen, these powerful political sponsors of the rhetoric of redistribution explicitly appropriated the discourse of the public interest, the common good and even patriotism, but they defined these ideas - 'the public', 'the nation' - in populist terms, as synonymous with the material needs of, as Roosevelt put it, 'the average man' (e.g. FDR vol. 4: 471; FDR vol. 5: 39, 211). In Britain, this style of rhetoric can be seen as a development from Gladstone's famous drawing of the electoral battle lines as 'the classes against the masses' or 'the classes against the nation' (Matthew 1995: 94-8). Gladstone had contrasted the sectional interests of privileged elites with the classless outlook of the nation as a whole largely in the context of non-economic issues such as parliamentary reform or the abolition of slavery. Later new liberals and socialists in turn sought to contrast the sectional, class-based economic behaviour of the rich with a classless national interest based upon the material needs of the ordinary citizen. In the United States, such rhetoric drew on a perennial republican theme, deeply entrenched in American political culture: the danger posed to the common good of the republic by the accumulation of power and influence in the hands of a self-centred minority (Gerstle 1989: 177).

In order to make this populist definition of the public interest more persuasive, advocates of redistribution stressed that their proposals expressed the traditions, values and interests of their national communities; that, among other things, redistribution expressed the fairness and solidarity of the national character. Beveridge argued that the introduction of a 
national minimum was 'a peculiarly British idea', and he added that his report on social insurance should not be seen as his own work but as an expression of the British people's deepest convictions: the Beveridge Report was 'the British people become articulate' (3.3.1943, London, PS: 143). 'We are not going to measure the strength of great powers only in their material forces', argued the young Winston Churchill in defence of Lloyd George's 'People's Budget' in 1909. In order for Britain 'to remain great and famous in the world' it was essential to promote 'the vigour and health of its population' and to deal with 'the present social and industrial disorders'. If Britain did not do so, he warned, 'our country will remain exposed to some fatal dangers against which fleets and armies are of no avail'. ${ }^{10}$ Roosevelt's attack on 'economic royalists' embedded economic redistribution within the broader narrative of the history of the republic. Opponents of the New Deal were now depicted as un-American, a point Roosevelt later made more explicit when he linked the American Revolution, a struggle for 'democracy in taxation', with the introduction of a more progressive income tax structure during the New Deal. Taxation according to ability to pay, argued Roosevelt, was 'the American principle', and the New Deal had 'Americanised the tax structure' by introducing greater progressiveness. As a result, Roosevelt argued that his administration had created 'a safer, happier, more American America', offering 'fidelity' to the true meaning of 'Americanism' (21.10.1936, Worcester, MA; 30.10.1936, Brooklyn, NY; 29.9.1936, Syracuse, NY; all in FDR vol. 5: $523-7,562,383){ }^{11}$

This social patriotism gave a clearer content to the rhetorical contrast between the common good and sectional interests. The rich and powerful were said to be benefiting themselves at the expense of their compatriots, while particular policy measures, such as a more progressive tax structure or the Beveridge Report, were portrayed as expressive of the fairness and solidarity inherent in the national character. National cultures and histories, as well as more straightforward arguments about enhancing the strength and power of the nation, were also recruited to the cause. As the Liberal MP Leo Chiozza Money sarcastically remarked in the parliamentary debate on the 'People's Budget', the opposition of the wealthy to higher taxation suggested that "we shall need a new definition of the word patriot: "Patriot: a person who won't pay"'. ${ }^{12}$

The ubiquity of this discourse of social patriotism challenges certain $a$ priori assumptions about the character of traditional progressive rhetoric. By invoking the nation, progressive politicians spoke about an identity that transcended class loyalties and contrasted a shared sense of community with the privilege enjoyed by a minority. In the speeches of Lloyd George, Roosevelt and others, the behaviour of the rich was presented as conflicting 
with the values of the nation rather than with the interests of the working class. Progressive politicians therefore did not disparage the ambitions of working families who sought to improve themselves and they spoke in terms designed to construct a political coalition between low- and middleincome voters against the wealthy minority. ${ }^{13}$ Once the welfare state was put into operation, argued Herbert Morrison, 'the middle classes as well as the working classes will have reason to bless these services' (13.12.1947, radio broadcast, $P R: 142$ ). For better or worse, the social democratic left has usually eschewed an electoral strategy and public ideology straightforwardly founded on an appeal to working-class interests.

\section{The lexicon of redistribution}

I have so far focused predominantly on the role played by emotional appeals and personal authority in shaping the rhetoric of redistribution. I have shown how powerful progressive politicians sought to arouse popular indignation at the prevailing distribution of wealth and opportunity, and how they embedded their criticisms in a discourse of the public interest and social patriotism. In the second part of this chapter I will focus more directly on the reasoned arguments that progressive politicians articulated in their oratory and, in particular, on the political ideals that they claimed redistribution could advance.

Two points should be stressed here. First, explicit references to material equality were handled rather gingerly. For example, when Roosevelt mentioned economic redistribution he would typically talk about sharing wealth 'more widely', or even more democratically, rather than more equally, and would often refer to 'concentrated' wealth rather than wealth inequality (e.g. FDR vol. 4: 271; FDR vol. 5: 162, 475, 521). Arguments directly emphasising the goal of material equality were not used with any frequency. Some of the politicians discussed here were simply not that comfortable with explicitly egalitarian language; others were, but probably judged that egalitarian language would be politically ineffective, since it was too controversial and offered an easy target for political opponents.

The second point to note about the political ideals invoked to support redistribution is that progressive politicians pressed into service a cluster of values judged to be more popular than the seemingly polarising goal of 'economic equality'. Many examples could be given here, but three stand out as particularly important: opportunity, security and fairness. In mentioning these words, it is of course hard to avoid summoning up the shades of Tony Blair or Bill Clinton. However, the words themselves are obviously open to diverse interpretations and the way in which they were used by 
politicians such as Lloyd George or Roosevelt was different from their use by present-day third wayists.

First, classic examples of redistributive public policy were presented as offering 'opportunity' to sections of the community previously denied it. The sheer elasticity and ambiguity of the concept of 'equal opportunity' can be an asset in political argument, since its apparently uncontentious, positive connotations command a broad public appeal. For example, 'opportunity' offered a link to the strong form of economic reciprocity discussed earlier: wealth and security were presented as rewards for, in Attlee's words, the 'hard work' of the majority, not the parasitic idleness or special privileges of the rich (7.2.1946, House of Commons, PP: 98). The provision of material resources and social services to the poor, either through social insurance, full employment policies or a more progressive tax structure, was in itself said to offer 'opportunity'. Since 'one cannot teach hungry children, or children who return each night to squalid homes', economic resources were necessary for individuals to make the most of their lives. The provision of decent jobs would extend the "opportunity of honourable, useful service' to the whole community (Beveridge 1944b: 6, 5). Crucially, this desire to spread 'opportunity' was not discussed as if it were purely a matter of fostering social mobility for a talented few. The bewitching image of a ladder out of poverty was not what progressive politicians had in mind. The new American ideal, announced Roosevelt, was not 'the dream of the golden ladder - each individual for himself', but rather of 'advancement ... along a broad highway on which thousands of your fellow men and women are advancing with you' (24.8.1935, radio broadcast, FDR vol. 4: 339). Stress was laid on collective rather than individual mobility, and the elimination of economic hardship was understood to be the necessary precondition of securing this goal.

Second, in the early twentieth century, security emerged as an authoritative word in the redistributive lexicon. Politicians often focused their rhetorical appeal on the concrete vulnerability of individuals and families to economic risk: the possibility of poverty and of hardship as much as actual poverty and hardship was a dominant theme in pro-welfare state rhetoric (and in welfare state political thought more generally: see Freeden 2003: 13-16). Lloyd George succinctly expressed the problem: 'Precariousness of work leads to the servitude of the worker. Certainty of work means freedom' (23.3.1910, London, BT: 302). The appeal of redistribution was that it would alleviate the distress caused by uncertainty about one's economic fate. 'Worry and anxiety are as inimical to health and happiness as the actual physical conditions of poverty', argued Attlee (7.2.1946, House of Commons, PP: 98). Social insurance, added Roosevelt, would make families 'free from this ever-present fear', enabling them to feel 'confidence' about 
their future (13.10.1936, Wichita KA, FDR vol. 5: 460). The very introduction of the terms 'social security' and 'social insurance' into popular political discourse in itself helped to drive this point home, conjuring up the need for collective precautions against the inherent risks of market economies. Security could only be guaranteed, went this argument, when the impact of economic risk was dampened by the entitlement of every citizen to a minimum income and access to social services (see e.g. FDR vol. 5: 574).

The discursive salience of 'security' was obviously related to the economic hardships and uncertainties that shaped voters' social experience: the depression of the 1930s, for example, was clearly the central reference point throughout New Deal rhetoric and in British political debates during and after the Second World War. But it would be wrong to conclude that the rhetorical force of this concept was relevant only to this particular period. Although the Great Depression was certainly a particularly stark instance, it would be odd to suggest that there was not a more general pattern of instability to be discerned in the operation of capitalist economies. In our own time, the salience of security also opens up interesting rhetorical connections that could be made between economic and international security, a link earlier made explicit by Roosevelt during the Second World War. ${ }^{14}$

Connected to these concrete objectives - 'securing for all citizens equal opportunity and equal security so far as human intelligence can achieve it' - was the third, and more abstract, ideal of fairness (H. Lehman, PDNC: 262-3). Fairness or social justice was regularly employed as a justification for equalising opportunities and security and as a more general demand for 'fair shares' for all. When used in political rhetoric, fairness concerned both the distribution of resources according to need and the allocation of burdens in proportion to the individual's capacity to contribute. In this first sense, fairness suggested an order of distributive priority. As Roosevelt suggested, 'the ambition of the individual to obtain for him and his a proper security, a reasonable leisure, and a decent living throughout life, is an ambition to be preferred to the appetite for great wealth and great power' (4.1.1935, message to Congress, FDR vol. 4: 17). Politicians argued that it was unjust to expect families to cope with great hardship when resources were available to assist them; it was only fair for the state to ensure that everyone enjoyed a minimum income. The demand for a national minimum was therefore stressed at the expense of more specifically egalitarian objectives (e.g. PS: 149). This goal, although more moderate than the radical egalitarianism sometimes ascribed to these political debates, seems to have reflected (and probably also influenced) popular perceptions of social fairness in the United States and Britain in the first half of the twentieth century (see e.g. Anderson 1990: 285-9, 315; Thane 1984: 899-900). But the 
cry for fair shares also made demands of public opinion. It called for the imaginative sympathy of more fortunate listeners, asking them to picture themselves placed in the straitened conditions of the poor and needy, and to recognise the role of luck in determining their place in the class structure. Fairness therefore also raised a second issue, the requirement of a greater contribution from those who were well-off. One objective of his 'People's Budget', said Lloyd George, was to place 'burdens on the broadest shoulders' and to ensure 'that wealth shall pay its fair share'. As he elaborated: 'There are many in the country blessed by providence with great wealth, and if there are amongst them men who grudge out of their riches a fair contribution towards the less fortunate of their fellow-countrymen they are very shabby rich men' (30.7.1909, Limehouse; 9.10.1909, Newcastle; BT: 156, 161, 145).

Overall, this rhetoric drew on a substantial body of progressive political thought about distributive questions. These were periods of frenetic but principled public intellectualism on the left: both left liberal and socialist ideologies furnished politicians with basic political insights that could then be rendered into more emotive and persuasive language suitable for a mass audience (I have discussed this theorising in Britain in Jackson 2007). The relationship between the populist rhetoric and the progressive political thought was complicated, and it can sometimes be hard to find precise affinities between the two enterprises (for a useful discussion of the methodological difficulties here see Bentley 1983: 137-43). Nonetheless, this intellectual productivity created an ideological environment from which politicians drew certain basic assumptions or generic conceptual forms, establishing a common sense that framed policy-making debates and gradually percolated into political speeches. Seen from a purely philosophical perspective, the political ideas used for rhetorical purposes were relatively unsophisticated and sometimes even crude, but they nonetheless bore some relationship to more conceptually complex ideologies. Roughly, the core insight that was absorbed from progressive political theory was that each individual required a certain share of material resources in order to attain certain widely valued political ideals: freedom, equal opportunity, security, social justice, democratic participation.

The classic example of this general claim was the widespread determination to wrest the rhetoric of liberty from the right by demonstrating that redistribution would in fact expand individual freedom. The obvious riposte from the opponents of progressive taxation and the welfare state was that such schemes would attack individual freedom by expropriating justly earned wealth; or by constraining the liberty of individuals to engage in commercial activity; or by greatly expanding the power of the state. 'What is this liberty that we have crucified? This liberty we have slain?' asked 
Democratic Senator Alben W. Barkley at the Democratic Party Convention in 1936:

Is it the freedom of workers to free collective bargaining? Is it the freedom of farmers to escape the loathsome peonage imposed on them by land and property speculators? Is it the freedom of investors to circumvent the secret devices of stock manipulators? Is it the freedom of bank depositors from the fear of loss of their savings? Is it the freedom of home owners and home lovers to protect and preserve their firesides?

The liberty that the New Deal opposed was only 'the liberty of small groups of people to pick the pockets of the American people' and 'the liberty of organised greed to pervert the agencies of the American government to their own enrichment'. The New Deal would in fact liberate individuals from 'economic serfdom' and 'wage slavery', added other speakers. Just as Lincoln opposed 'those who found monetary profit in holding fellow human beings in bondage, so against Roosevelt there are united those who find pecuniary gain in the industrial serfdom of women and children' (Barkley et al. all in PDNC: 47, 21, 227). The political language of the opponents of redistribution, it was argued, simply made a mockery of the meaning of freedom and individual rights: 'the right to live involves the right to have the means to sustain life' ( $\mathrm{P}$. McNutt in PDNC: 230). ${ }^{15}$ Progressives were not prepared to cede the value of liberty to the right, and nor were they willing to accept that the ideological contest between right and left should be caricatured as one that opposed 'liberty' to 'equality'.

The rhetoric of redistribution was therefore constructed by politicians from conceptual materials and ideological traditions that were left-liberal or social democratic or socialist in provenance. It was not rhetoric that sought to articulate populist sentiments disconnected from existing ideological alignments in order to transcend or triangulate between existing political languages and organisations. It was rhetoric imbued with the arguments, assumptions and strategies of the left and designed to confront the arguments, assumptions and strategies of the right.

\section{'We can do it'}

My discussion so far has described a rhetoric of economic populism and social patriotism, crafted to mobilise low- and middle-income citizens in a political coalition against the economic interests of the rich, a populism with a substantive political content drawn from left-liberal and socialist political thought. My final observation about the character of the rhetoric of redistribution concerns the deeper assumptions about political agency 
that it made, and that it sought to disseminate to a wider public in the course of political debate.

This political rhetoric communicated an important message about the limits of the individual's responsibility for their economic fate, both in a backward-looking and a forward-looking sense. In a backward-looking sense, as the emphasis on security also implied, poverty and unemployment were depicted as the consequences of social processes, of unpredictable market fluctuations that simply were not susceptible to individual control. This could lead to vivid oratory that linked this thought to the economic populism and the view of social justice discussed earlier. Lloyd George conjured up the case of 'a good workman' made unemployed:

whose fault is it? Perhaps some greedy financiers, it may be in some other country altogether, who, in their eagerness to get very rich, overstep the bounds of prudent speculation. There is a crash. A panic follows. The trade routes are blocked with the debris, and hundred of thousands, nay, millions of workmen in many lands are forced to remain idle until the roads are cleared and traffic is resumed ... Is it just, is it fair, is it humane to let them suffer privation? (1.10.1908, Swansea, BT: 54)

Similarly, it was argued that great individual wealth was the result of social cooperation, dependent upon the efforts of many individuals and social institutions, and not simply the heroic entrepreneurship of a Henry Ford or a William Morris. Roosevelt cited the words of Andrew Carnegie: 'Where wealth accrues honourably, the people are always silent partners' (19.6.1935, message to Congress on tax revision, FDR vol. 4: 272).

Just as there were limits to individual responsibility in this backwardlooking sense, there were also limits in a forward-looking sense: individuals could not solve these problems on their own. This highlighted the need for collective action to overcome the unfairness produced by market activity. As Beveridge argued: 'Poverty is a crime, and the only question is, who is the criminal? Not, I suggest, the poor man, but the society which permits needless poverty' (Beveridge 1944b: 8). The rhetoric of redistribution conveyed confidence, even a breezy optimism, about the capacity of collective action to solve social problems. The 'socialist principle', argued Herbert Morrison, was 'to do things collectively for the individual citizens . . . which individuals could not well do for themselves'. For example: 'the citizen cannot adequately protect himself and his family by his own unaided effort. He must combine. Alone he risks collapse; but he can, by co-operating and by creating a fund, protect his family and his dependants from poverty and want' (19.6.1947, London, PR: 38, 39). Of course, these ideas were not restricted to those who self-identified as socialists: left-liberal politicians expressed similar sentiments. Frances Perkins, Roosevelt's Secretary of Labour, sounded the same note in a 1935 radio broadcast as 
she introduced the nation to social security: it was one example, she said, of 'using co-operation through government to overcome social hazards against which the individual alone is inadequate' (2.9.1935, in Zinn 1966: 281).

Such rhetoric sought to redraw the accepted boundary between individual and collective responsibility, and to persuade voters that collective action through the state was a plausible and efficient means of addressing social harms. To this end, social problems were said to be analogous to other, more familiar crises, which had previously been addressed through collective action. Just as preventive or ameliorative measures were undertaken to counteract natural disasters, argued Roosevelt, 'the strong arm of the nation' was 'needed equally in taking measures to prevent economic disasters which are not natural, but are made by man' (25.4.1936, New York, FDR vol. 5: 178). Indeed, this point could be pushed further. As Beveridge noted, 'depressions of trade are not like earthquakes or cyclones; they are man-made', which suggested that a well-designed economic system might even be able to avert them altogether (Beveridge 1944a: 249). Roosevelt also claimed that curing social problems represented a challenge similar to earlier struggles against 'the ravages of diseases that years ago were regarded as unavoidable and inevitable' (24.8.1935, radio broadcast, FDR vol. 4: 341). This medical image also invoked the spirit of scientific progress. The implication was that social reform represented both a natural extension of scientific inquiry and the cutting edge of human ingenuity: reformers were engaged in 'social pioneering', said Roosevelt, likening them to the builders of the United States (13.4.1936, Baltimore, FDR vol. 5: 165; see too Plotke 1996: 171-4).

Why is this emphasis on collective agency significant? Communicating to the electorate the conviction that 'we can do it' is obviously critical when mobilising public support for ambitious measures of social reform. Conquering scepticism about the efficacy of political action should therefore be a key priority in any successful progressive rhetoric, and it is salutary to remember that radical politicians of the past had to face and conquer deep-seated doubts about state capacity. Although it is a familiar point, it is worth remembering in this context that present-day progressive rhetoric is characterised by almost precisely the opposite view: it emphasises the constraints on government action; the nation-state's inability to control and shape economic forces; and the failure of the state-led model of social reform. Just as present-day politicians on the left have turned away from contrasting social patriotism with the sectional interests of the wealthy, and just as the same politicians have lost a public lexicon shaped by leftliberal or socialist political thought, today's progressive politicians express 
fatalism about the prospects for collective action and doubt about the state's role as an agent of the common good.

\section{Conclusion}

This chapter has tried to dislodge some entrenched assumptions about the political rhetoric used in the past to mobilise support for economic redistribution. Far from preaching a leftist fundamentalism explicitly targeted at the working class, leading radical politicians in fact employed a more moderate discourse of the public interest that appealed to national rather than class identity. They mobilised popular support by introducing a negative characterisation of the social contribution made by the wealthy and depicting low- and middle-income voters as allies in the national cause. The political content of this social patriotism was determined by the appropriation of important and prestigious values. A fair and democratic society, it was argued, should ensure security and opportunity for all; adequately reward the contribution made by the low-paid; and restrict the economic and political power wielded by the wealthiest. More general points about collective responsibility and the power of the democratic state were also articulated to inspire confidence in the efficacy of redistributive solutions. As I indicated at the outset, my task here has been primarily interpretive. Although I do think that it would be feasible to employ these rhetorical strategies in contemporary political controversies, I have not sought to make this case in this chapter. However, the evidence assembled here does suggest that, before any further electoral strategies are presented as improving upon a caricatured ancestral leftist fundamentalism, political strategists should at least acknowledge the authentic character of the rhetoric of redistribution. ${ }^{16}$

\section{Notes}

1 An earlier version of this chapter was presented at the third Rethinking Social Democracy Conference held at Sheffield University in June 2006 and at several other conferences and seminars. I am grateful to all those who commented on it in its earlier guise. Particular thanks are due to Gregg McClymont, Martin McIvor and Zofia Stemplowska for reading and commenting on the penultimate draft.

2 My quotes from these speeches and broadcasts will adopt the following conventions. For my chief sources, I will indicate in brackets after each quote the date and place of the speech (or identify it as a radio broadcast), along with one of the following abbreviations to identify its location in print:

BT Lloyd George, D. (1910) Better Times: Speeches by D. Lloyd George

FDR Roosevelt, F. D. (1938-50) The Public Papers and Addresses of Franklin D. Roosevelt

PDNC Democratic Party (1936) The Proceedings of the Democratic National 
Convention 1936

PR Morrison, H. (1949) The Peaceful Revolution: Speeches by the Rt. Hon. Herbert Morrison

PP Attlee, C. R. (1946) Purpose and Policy: Selected Speeches

PS Beveridge, W. (1943) The Pillars of Security and Other War-time Essays and Addresses

References to parliamentary speeches will be given in the end-notes.

3 One study in this vein has greatly influenced my approach: Albert Hirschman's The Rhetoric of Reaction (1991), from which I have also adapted the title of this chapter.

4 For contemporary emphasis on this point, see Graetz and Shapiro 2005: 226-35; Fabian Society 2005: 16-34.

5 My understanding of the technique of 'rhetorical redescription' is derived from Skinner 1996: 138-80; Skinner 2002: 182-6.

6 Dalton was quoting H. G. Wells: H. Dalton, 9.4.1946, Parl. Deb., 5th Ser., vol. 421 , col. 1835.

7 See also the similar point made by the Labour MP James O'Grady in support of the introduction of old-age pensions, 15.6.1908, Parl. Deb., 4th Ser., vol. 190, col. 621 .

8 See also the recurring criticism of the greed and selfishness of the rich in PDNC, e.g. 21-3, 47-8, 212-13, 269. For the appropriation of this rhetorical style and the epithet 'economic royalists' by US trade unionists, see Gerstle 1989: 169-74.

9 Here I depart from Aristotle, who sees ethos as a matter of speakers projecting a positive image of their character solely through their rhetoric, not because of any powerful political offices they happen to hold or any other prior assumptions about the kind of person they are (Aristotle 1984, Bk 1, Ch. 2: 2155). But in the case I am investigating here, it seems to me significant to understanding the persuasive force of redistributive rhetoric that powerful politicians placed the authority of their offices behind it.

10 W. S. Churchill, 3.5.1909, Parl. Deb., 5th Ser., vol. 4, col. 854.

11 For the background to the 'Americanism' of the New Dealers, see Gerstle 1989, especially 8-9, 156-8, 166-95, 216-49.

12 L. Chiozza Money, 17.5.1909, Parl. Deb., 5th Ser., vol. 5, col. 46.

13 This was one reason for Lloyd George's focus on the landed aristocracy rather than other wealthy groups, as a means of exploiting middle-class resentment against the aristocracy: see Grigg 1997: 213.

14 For example, in Roosevelt's invocation of the 'four freedoms': freedom of speech, of worship, from want and from fear (6.1.1941, message to congress, FDR vol. 9; 7.1.1943, state of union address, FDR vol. 12: 30-4).

15 See also the same point made by Labour MP James Griffiths in the parliamentary debate on the Beveridge Report, 18.2.1943, Parl. Deb., 5th Ser., vol. 386, col. 1966.

16 Indeed, it should be acknowledged that in the USA Democratic politicians and strategists have very recently shown signs of gravitating towards an 'economic 
populism' which goes some way towards meeting the concerns of this chapter: see e.g. Toner 2007.

\section{References}

Addison, P. (1975) The Road to 1945 (London: Cape).

Anderson, L. (1990) Making a New Deal: Industrial Workers in Chicago 1919-39 (Cambridge: Cambridge University Press).

Aristotle (1984) Rhetoric, in The Complete Works of Aristotle, ed. J. Barnes (Princeton: Princeton University Press).

Attlee, C. R. (1946) Purpose and Policy: Selected Speeches (London: Hutchinson \& Co.).

Bentley, M. (1983) 'Party, doctrine and thought', in M. Bentley and J. Stevenson (eds), High and Low Politics in Modern Britain (Oxford: Oxford University Press).

Beveridge, W. (1943) The Pillars of Security and Other War-time Essays and Addresses (London: Allen \& Unwin).

Beveridge, W. (1944a) Full Employment in a Free Society (London: Allen \& Unwin).

Beveridge, W. (1944b) Security and Adventure (London: Council for Education in World Citizenship).

Brewer, M., Goodman, A., Muriel, A., Phillips, D. and Sibieta, L. (2008) Poverty and Inequality in the UK: 2008 (London: Institute for Fiscal Studies).

Clarke, P. (1974) 'Introduction' to J. A. Hobson, The Crisis of Liberalism (Brighton: Harvester).

Cripps, S. (1946) Democracy Alive: a Selection from Recent Speeches by the Rt. Hon. Sir Stafford Cripps (London: Sidgwick \& Jackson).

Cronin, J. (1984) Labour and Society in Britain 1918-79 (London: Batsford).

Economist, The (2005) 'The flat tax revolution', 14 April.

Democratic Party (1936) The Proceedings of the Democratic National Convention 1936 (Washington, DC).

Fabian Society (2005) Why Life Chances Matter (London: Fabian Society).

Freeden, M. (1996) Ideologies and Political Theory (Oxford: Oxford University Press).

Freeden, M. (2003) 'The coming of the welfare state', in T. Ball and R. Bellamy (eds), The Cambridge History of Twentieth Century Political Thought (Cambridge: Cambridge University Press).

Gerstle, G. (1989) Working Class Americanism: the Politics of Labor in a Textile City (Cambridge: Cambridge University Press).

Graetz, M. J. and Shapiro, I. (2005) Death by a Thousand Cuts (Princeton: Princeton University Press).

Grigg, J. ([1978] 1997) Lloyd George: the People's Champion 1902-1911 (London: Penguin).

Hirschman, A. (1991) The Rhetoric of Reaction (Cambridge, MA: Harvard University Press).

Jackson, B. (2007) Equality and the British Left: a Study in Progressive Political Thought 1900-64 (Manchester: Manchester University Press). 
Lloyd George, D. (1910) Better Times: Speeches by D. Lloyd George (London: Hodder \& Stoughton).

Matthew, H. C. G. (1995) Gladstone Volume 2: 1875-1898 (Oxford: Oxford University Press).

Morrison, H. (1949) The Peaceful Revolution: Speeches by the Rt. Hon. Herbert Morrison (London: Allen \& Unwin).

Plotke, D. (1996) Building a Democratic Political Order: Reshaping American Liberalism in the 1930s and 1940s (Cambridge: Cambridge University Press).

Roosevelt, F. D. (1938-50) The Public Papers and Addresses of Franklin D. Roosevelt (New York: Russell \& Russell).

Skinner, Q. (1996) Reason and Rhetoric in the Philosophy of Hobbes (Cambridge: Cambridge University Press).

Skinner, Q. (2002) Visions of Politics Volume 1: on Method (Cambridge: Cambridge University Press).

Stears, M. (2005) 'The vocation of political theory: principles, empirical inquiry and the politics of opportunity', European Journal of Political Theory, 4.

Thane, P. (1984) 'The working class and state "welfare" in Britain, 1880-1914', Historical Journal, 27.

Toner, R. (2007) 'A new populism spurs Democrats on the economy', New York Times, 16 July.

White, S. (2003) The Civic Minimum (Oxford: Oxford University Press).

Zinn, H. (ed.) (1966) New Deal Thought (Indianapolis: Bobbs-Merrill Co.). 